\title{
Ellipsis
}

2017

\section{The Humanity of Electric Sheep: A Lacanian Psychoanalytic Perspective}

Richelle V. Finn

University of New Orleans, New Orleans

Follow this and additional works at: https://scholarworks.uno.edu/ellipsis

\section{Recommended Citation}

Finn, Richelle V. (2017) "The Humanity of Electric Sheep: A Lacanian Psychoanalytic Perspective," Ellipsis: Vol. 44 , Article 25.

DOI: https://doi.org/10.46428/ejail.44.25

Available at: https://scholarworks.uno.edu/ellipsis/vol44/iss1/25

This Literary Criticism is brought to you for free and open access by the Department of English and Foreign Languages at ScholarWorks@UNO. It has been accepted for inclusion in Ellipsis by an authorized editor of ScholarWorks@UNO.For more information, please contact scholarworks@uno.edu. 


\title{
The Humanity of Electric Sheep: A Lacanian Psychoanalytic Perspective
}

\author{
Richelle Finn
}

In Philip K. Dick's masterpiece 1968 science fiction novel Do Androids Dream of Electric Sheep?, World War Terminus has devastated the population of Earth and left the planet almost uninhabitable, compelling survivors to flee to Mars or one of several colony planets. The emigrants are given free android servants as an incentive to serve them in space. The androids are highly intelligent, sophisticated, and efficient; so much so that they are nearly indistinguishable from human beings. Occasionally, an android slave kills their master and flees Mars for safe haven on Earth. Thus, bounty hunters are employed by police agencies to protect the small but resolute communities of humans who reject emigration and those who cannot emigrate because the harmful, unsafe effects of living on the post-apocalyptic Earth. The main character of the novel is one of these bounty hunters named Rick Deckard. Throughout the course of the novel as he destroys or "retires" six of the aforementioned escaped androids, Deckard's sense of identity is shaken; he begins to question if he might be an android too and not a human like he is led to believe, due to his ever increasingly cold, distant nature.

Do Androids Dream of Electric Sheep? explores the ethical implications of enslaving the androids and, more importantly, androids are used as a tool to analyze and identify the true essence of humanity. Humans claim that the androids do not possess empathy; therefore, humanity's essence must be in their sense of empathy, or so their logic dictates. In the novel, a polygraph-like device called the Voight-Kampff Machine is used to determine if a subject shows signs of empathy in order to determine if the individual is an android or a human; yet the question remains, should empathy really be the defining quality of determining humanity?

With this in mind, I will examine Philip K. Dick's Do Androids Dream of Electric Sheep? using psychoanalytic criticism, specifically French psychoanalyst Jacques Lacan's mirror stage theory. In Lacan's article entitled "The mirror stage as formative of the function of the I as revealed in psychoanalytic experience," Lacan describes the mirror stage of a child's development as, "the transformation that takes place in the subject when he assumes an image -whose predestination to this phase-effect is sufficiently indicated by the use, in analytic theory, of the ancient term imago," (Lacan 503). Additionally, according to the definition of the theory provided by the University of Hawaii's English Department in their article "Lacan: The Mirror Stage," "...human infants pass through a stage in which an external image of the body (reflected in a mirror, or represented to the infant through the mother or primary caregiver) produces a psychic response that gives rise to the mental representation of an 'I'." To clarify, Lacan refers to a milestone in an infant's psychological development in which that when the baby looks in a mirror, they come to the realization that the image they are seeing is not just any 
ordinary image, it is actually themselves in the mirror. This "a-ha" moment of self-realization is what Lacan's Mirror Stage Theory is based on, and he develops an immensely complex set of hypotheses stemming from this very real moment in every human's life.

Lacan's ideas that arose from his studies of the mirror stage are fascinating to say the least, though at times it can be quite challenging to comprehend. As Lacan explains,

This... specular image by the child at the infans stage... would seem to exhibit in an exemplary situation the symbolic matrix in which the $I$ is precipitated in a primordial form, before it is objectified in the dialectic of identification with the other, and before language restores to it... as subject. This form would have to be called the Ideal-I... This form situates the agency of the ego, before its social determination, in a fictional direction, which will always remain irreducible for the individual alone, or rather, which will only rejoin the coming-into-being...of the subject asymptotically, whatever the success of the dialectical syntheses by which he must resolve as $I$ his discordance with his own reality (Lacan 503)

Furthermore, in the University of Hawaii's article "Lacan: The Mirror Stage,"

The infant identifies with the image, which serves as a gestalt of the infant's emerging perceptions of selfhood, but because the image of a unified body does not correspond with the underdeveloped infant's physical vulnerability and weakness, this imago is established as an Ideal-I toward which the subject will perpetually strive throughout his or her life. The mirror stage establishes the ego as fundamentally dependent upon external objects, on an other. ...this "other" will be elaborated within social and linguistic frameworks that will give each subject's personality its particular characteristics ("Lacan: The Mirror Stage").

What this means is that when an individual comes to the realization that the image in the mirror is of themselves, they further realize that it must be how others will perceive of them to be. This can be a problem, as the image that one sees does not necessarily align with how they perceive themselves in their mind's eye. A person will then continuously strive throughout their life to bring that ideal self, or the Ideal-I, into fruition. The image in the mirror becomes this "Other", through which an individual will always scrutinize and pass judgment on, for it is not their ideal selves.

Using these same principles outlined above, I hypothesize that in Philip K. Dick's novel Do Androids Dream of Electric Sheep?, the androids are the humans' artificial and technological Other. The androids thus perform the function of the mirror image of oneself, but they do so on a societal, not an individual, scale. The humans' anxieties about the androids focuses on the uncertainty of what being a human entails. As Philip K. Dick himself stated, 
The purpose of this story as I saw it was that in his job of hunting and killing these [androids], Deckard becomes progressively dehumanized. At the same time, the [androids] are being perceived as becoming more human. Finally, Deckard must question what he is doing, and really what is the essential difference between him and them? And, to take it one step further, who is he if there is no real difference? (Grace "Literary Contexts in Novels: Philip K. Dick's "Do Androids Dream of Electric Sheep?").

Hence, I believe that Dick uses the conflict of determining the biological from the artificial to illustrate Lacan's psychoanalytic theory of the mirror stage and to showcase the importance in mankind's continual search for determining what humanity is and who we really are.

In order to help confirm my hypothesis, some research questions I sought to answer are as follows: What does the idea of humans wanting to own biological animals as pets instead of artificial ones tell us about the mindset of the characters in the novel? How does it represent the dichotomy of humans versus androids; the notion that androids are not real people? What does the artificial toad at the end of the novel symbolize about Deckard and his sense of identity and humanity? Is the Voight-Kampff Machine intrinsically flawed? Why is Rick Deckard's sense of identity is shaken due to his interactions with the androids? Are humans really any different than androids? Lastly, how is this all related to Lacanian psychoanalysis, specifically Lacan's Mirror Stage Theory?

In Klaus Benesch's article "Technology, Art, and the Cybernetic Body: The Cyborg as Cultural Other in Fritz Lang's 'Metropolis' and Philip K. Dick's 'Do Androids Dream of Electric Sheep?"', the role of cyborgs/androids are examined in the works of Fritz Lang's Metropolis and Dick's Do Androids Dream of Electric Sheep? according to Lacanian theory; specifically he uses the Mirror Stage theory to highlight how Philip K. Dick shows the main conflict of differentiating humanity from androids using the Voight-Kampff machine as being fundamentally flawed. Essentially, the notion that androids do not possess empathy therefore humans must possess this trait is proven false as Deckard interacts with the androids more and more.

First, Benesch addresses the fact that the androids look identical to humans in every way, physically speaking. "As with the androgynous characters,... we can neither be wholly assured of the visual markers of the human nor of those which define the identity of the cyborg. On the contrary, the very essence of the imagery of the man-machine turns on the fact that it resembles as much as it estranges the organic body" (Benesch 389-390). This makes the use of the psychological test and the Voight-Kampff machine crucial in determining a human from an android. The androids look identical to humans; this makes the androids, as in the Lacanian theory, an Other. In this case, they are the artificial, machinal or technological Other. "Similar to Lacan's heterodoxical concept of identification," Benesch explains, 
the machinal Other of this story appears to be but a doubling and distorted image of the spectator, a direct product and brainchild of the humans' mind. Moreover, Deckard's attempt to stalk and finally detect the technological Other through a combination of projections and "gazing" refers to the Lacanian emphasis on the gaze as marker of the child's fascination with his/her own mirror image (390).

This means that Deckard slowly realizes that the androids are not just some technological Other that humanity has created for itself to use as we please, but that the androids are actually a reflection on humanity itself. Humanity can be just as emotionless, cold, and logical as the androids, which makes sense as humans created the androids in their own image.

As the main character Rick Deckard hunts down and "retires" the six fugitive androids one by one, he slowly begins to question his own humanity. He sees that the androids are not so different from humans at all, as one of the androids is even an opera singer, for example. Yet, the fault of not being able to truly differentiate between a human and an android does not lie within Deckard, but within the parameters of the Voight-Kampff test.

As Benesch suggests,

the test is devised according to a preset notion of what it means to be a machine, that is, the lack of emotional responses, it is doomed to replicate endlessly the false premises of the human observer.... the whole design rests on an inherent paradox: by presupposing the disinterestedness and emotional aloofness of the experimenter, the Voight-Kampff scale betrays the same psychological markers as the non-person it seeks to identify.

The difference, then, between artificial and "natural" existence does not originate within the machine; rather it results from the paradoxical desire rampant in technologically advanced cultures to define humanity against the technological as Other and alien to human nature. It is thus... always the humans, and not the androids, who dream of electric sheep (390).

It is through the Lacanian mirror stage theory that Benesch determines that the test itself is irrefutably flawed.

In Irina-Ana Drobot's article "Flower-Power Tantra By Claudia Golea And Do Androids Dream of Electric Sheep? By Philip K. Dick: Creating A Different Reality," Flower-Power Tantra and Do Androids Dream are compared and contrasted by the ways in which the texts help break our sense of what reality is and how the respective stories are told through these alternate realities. Specifically, Drobot delves into the nature of humans' relationship with the androids, and tells us how the androids are being treated as slaves and not as sentient beings with the ability to write their own destinies. This goes a little into critical race theory, as Drobot compares the humans' treatment of the androids to "the problem of minorities. At some point, one android notices that even the 
animals have become protected by the law, that they have become sacred, while the androids are withdrawn, a word created to express their killing" (Drobot 43). Humans have now divided beings into a new binary: the biological and the artificial. It is the fact that the androids are an artificial life form and not biological that makes humans value animals over androids. This further demonstrates how the humans represent Lacan's ideal I while the androids are the technological Other that humans must scrutinize and pass judgment on.

Drobot has also recognized the main quality that humans use to justify the hunting down and killing the androids in the novel, and that is the supposed lack of empathy in the androids. This idea the humans hold that empathy is an inherent quality of humanity is called into question: "people are distinguished by their ability to feel empathy. But is this really true? The novel seems to question this idea at some point. The hero, the bounty hunter, is determined to wonder at some point whether he himself is not an android. How come that he can kill androids in cold blood? Did he do that psychological test himself?" (Drobot 43). Deckard's own humanity is addressed by Drobot as she describes how, "The memories of the bounty hunter could be false memories, i.e. the memories of another, referring to psychology, Freudian psychoanalysis and all sorts of experiments, as is the case in the novel, with a generation of androids inside whose minds memories of human beings were introduced" (Drobot 43). This is evidence of the uncertainty of what qualifies as a measure of humanity that is presented in the novel. Drobot further addresses that a psychological test for empathy is flawed, and concludes that Dick could be addressing the problems in the field of psychology. As she explains, "Psychological tests sometimes prove inadequate for the recognition of androids. It could be some judgment directed towards the accuracy of psychological tests given at work or in other situations, or of psychology in general, an often controversial science" (Drobot 43). This conclusion supports my theory that having empathy as the one factor for determining humanity is a big problem and is unfounded. Therefore, the Voight-Kampff machine and the psychological tests themselves are incorrect.

Jill Galvan's article "Entering the Posthuman Collective in Philip K. Dick's 'Do Androids Dream of Electric Sheep?'" addresses many different aspects of posthumanism within the novel, including the evolution of humanity, the blending of nature with technology, and the search for the self within in the twenty-first century. The use of empathy as the quintessential human quality is called into question, and Galvan analyses this according to different aspects of psychology and philosophy. Galvan first tells us of how futile it is to really differentiate humans from androids, since both are alike in many ways. Humans can be cold, heartless, and prone to violence at times, and these qualities can be just as intrinsic to a human's life as it is to an android. She explains that,

The electronic image brings this question to the fore, and further it reveals the firm boundaries of the human collective as wholly fictional. Dick's human characters naively pride themselves on their empathic unity and derogate technological constructs as inherently secondary to biological ones... Yet as we have seen, machines have not only infiltrated the human 
collective, but have also become an integral part of the establishment - an ineradicable element of human day-to-day existence (Galvan 418).

Many scholars believe that life in the twenty-first century will be one of Posthumanism, and the biological will be integrated with the technological, and Dick's Do Androids Dream of Electric Sheep? demonstrates just how much that is a true statement.

Though not only are humans more like androids in their lack of empathy at times and the use of technology in their everyday lives, but the reverse is also shown to be true; androids can be just as empathic as humans. Galvan tells us that, "... a few of the androids Rick deals with exhibit what appears to be caring for their own kind and even, in some cases, for the humans with whom they interact." (414). She describes one scene where the android Rachael kills Deckard's pet goat in a fit of supposed jealousy, or that is what it appears to be:

[Deckard] returns home to discover that Rachael has pushed [his] goat off the roof Why? Because she is jealous of his love for the goat, or in revenge for his killing her friends...? Whichever interpretation one chooses, the action is not consistent with the official picture of android psychology, which like Dick's essays insists that androids are incapable of feeling loyalty or indeed feeling anything at all (Galvan 415).

Galvan proclaims that if the Voight-Kampff machine could analyze the android's actions in those instances, then, "...the scenarios that Rick proffers to his android suspects would not, should they generate an apathetic response, differentiate androids from modern Americans" (415). Not only do the humans act like androids, but the androids also act like humans. So, are humans and androids so different?

Galvan concludes that mankind trying to distinguish humans from androids is a futile effort. The androids do have empathy and resemble human fallacies regardless of what the humans might want to believe.

Sherryl Vint takes a different approach to analyzing the novel in her article "Speciesism and species being in Do Androids Dream of Electric Sheep?" and explores the role of biological and artificial animals within the larger context. It is her belief that literary critics have thoroughly analyzed the role of the androids and have ignored the importance of animals in the text. Vint's intent of the article is "to focus attention on an aspect of the original text neglected in both the film adaptation and by [literary] criticism: the importance of animals, [both artificial ones] and real. Do Androids Dream of Electric Sheep? develops its ideas about being human through two comparisons: animals and androids" (111). She uses some psychoanalysis in the article though the main theoretical framework used is Marxism; specifically, the novel is analyzed according to Marx's species being theory.

In her article, Vint is not shy about her disappointment in the lack of analysis on the role that animals play in the novel within the literary critic community. She believes that, 
only by realizing the centrality of animals can we perceive all the implications of Deckard's change. It is not... that Deckard risks becoming increasingly like the androids through his work as a bounty hunter; rather, the risk faced by Deckard and other humans in the novel lies in realizing that they already are android-like, so long as they define their subjectivity based on the logical, rational, calculating part of human being (Vint 112).

Vint also addresses the importance of the final scene of the novel, as she describes the way

the novel's final scene, Iran orders electric flies for the electric toad, a sign of love for her husband who is "devoted to it" beyond reason, beyond rationality, beyond reciprocity.... In this act of care for the electric toad (even though it has no economic status as it is not 'real') Iran and Deckard begin to find a way out of commodity fetishism. They are learning to treat the toad with kindness rather than as a possession because it is the social relationship--not the ontological status of the toad--that counts (121).

For Vint, the final scene completes Deckard's story arc of realizing that humans and androids, the biological and the artificial, are not so different; how of little importance it is to try and make one superior to the other.

Vint also addresses the failure of the Voight-Kampff Test and how an android can reasonably answer the questions in a manner consistent with human thought and logic but deem them not human because it does not elicit an empathic response. For example,

During her empathy test, when told about a banquet at which dog was served, Luba responds, 'Nobody would kill and eat a dog... They're worth a fortune' (103), a non-empathic response that marks her as an android, but which is nonetheless consistent with attitudes toward animals displayed by the human characters... it is worth noting that most of Dick's audience would fail the Voight-Kampff test. Its questions--about topics such as boiling live lobster, eating meat, or using fur--denote things that are commonplace rather than shocking in our world (Vint 114).

Vint's analysis of the role of animals in the novel, the cold logic demonstrated by humans, and the instances of empathy shown by the androids all are important pieces of evidence that help support my hypothesis. With this in mind, it is only fair to determine that the empathy test is highly illogical and inconsistent with human nature.

It is interesting to note that Jacques Lacan's psychoanalytic theories and Philip K. Dick's fictional works are both considered to be within the Postmodernism Movement. Furthermore, in January 1966, "With the publication of Ecrits, a collection of [Lacan's] writings which includes the essay on the Mirror 
Stage, Jacques Lacan gains a wider audience among intellectuals," (Felluga "Lacan II: On the Structure of the Psyche"). Though his essay on the Mirror Stage was originally published in 1949 , readers did not really take notice of it until the publication of Ecrits in 1966. Shortly thereafter, in 1968, the first edition of Philip K. Dick's Do Androids Dream of Electric Sheep? was published. It could be merely coincidence, but it is curious that there are so many parallels found in Lacan's and Dick's works and so many examples of Lacan's Mirror Stage Theory found in Dick's novel that one has to wonder if Dick actually had the theory in mind when Dick wrote it, even if only in his subconscious.

Whether or not Dick had Lacan's Mirror Stage Theory in mind, consciously or subconsciously, while writing his novel or not, one cannot dispute that there does seem to be a connection between these two works of Posthumanist thought. I believe that this essay is only scratching the surface of what philosophical, psychoanalytical, and Posthumanist insights one can find in Do Androids Dream. Dick's beloved science fiction classic novel's importance is still vital in our continual search for answering questions of identity; what being human really is, if empathy really is a defining characteristic of humanity, and the role technology has on us as a society and as individuals in the future.

\section{Works Cited}

Benesch, Klaus. "Technology, Art, and the Cybernetic Body: The Cyborg as Cultural Other in Fritz Lang's 'Metropolis' and Philip K. Dick's 'Do Androids Dream of Electric Sheep?'." Amerikastudien / American Studies, 1999, 379.

Dick, Philip K. Do Androids Dream of Electric Sheep? Doubleday, 1968.

Drobot, Irina-Ana. "Flower-Power Tantra By Claudia Golea And Do Androids Dream of Electric Sheep? By Philip K. Dick: Creating A Different Reality." Scientific Journal of Humanistic Studies, 2015, 41-43.

Felluga, Dino. "Lacan II: On the Structure of the Psyche." Introduction to Psychoanalysis. Purdue University, 2002.

Galvan, Jill. "Entering the Posthuman Collective in Philip K. Dick's 'Do Androids Dream of Electric Sheep?'." Science Fiction Studies, 1997, 413.

Grace, Dominick. "Literary Contexts in Novels: Philip K. Dick's "Do Androids Dream of Electric Sheep?" Literary Contexts in Novels: Philip K. Dick's 'Do Androids Dream of Electric Sheep?', 2006, 1.

Lacan, Jacques. "The mirror stage as formative of the function of the I as revealed in psychoanalytic experience." Cultural Theory and Popular Culture. A Reader, 1949, 287-292.

"Lacan: The Mirror Stage." Lacan: The Mirror Stage. English Department. University of Hawaii, n.d., http://www.english.hawaii.edu.

Vint, Sherryl. "Speciesism and species being in Do Androids Dream of Electric Sheep?" Mosaic: A journal for the interdisciplinary study of literature, 40.1, 2007, 111+. 